\title{
Organic carbon isotope values from the Late Permian Seis/Siusi succession (Dolomites, Italy): Implications for palaeoenvironmental changes
}

\author{
Susann Siegert*, ${ }^{*}$, Sonja H. Kraus ${ }^{1}$, Wolfgang Mette $^{2}$, Ulrich Struck ${ }^{3}$ and Christoph Korte ${ }^{1,4}$ \\ ${ }^{1}$ Institut für Geologische Wissenschaften, Freie Universität Berlin, Malteserstr. 74-100, 12249 Berlin, Germany, \\ e-mail: susann.siegert@mfu-berlin.de \\ ${ }^{2}$ Institut für Geologie und Paläontologie, Universität Innsbruck, Innrain 52, 6020 Innsbruck, Austria \\ ${ }^{3}$ Museum für Naturkunde, Leibniz-Institut für Evolutions- und Biodiversitätsforschung an der Humboldt-Universität zu Berlin, 10115 Berlin, \\ Germany \\ ${ }^{4}$ Department of Geography and Geology, University of Copenhagen, Øster Voldgade 10, 1350 Copenhagen K, Denmark
}

Received 8 December 2010

Accepted 22 February 2011

Published 3 August 2011

\section{Key Words}

carbon isotope stratigraphy

microfossils

organic matter from land plants

P-T boundary

Southern Alps

\begin{abstract}
The Permian-Triassic boundary is marked by a globally prominent negative carbon isotope excursion traceable in marine carbonates and organic matter. In the shallow marine carbonate succession at Seis/Siusi (Dolomites, Italy), the $\delta^{13} \mathrm{C}_{\text {carb }}$ and $\delta^{13} \mathrm{C}_{\text {org }}$ signatures follow the general Permian-Triassic boundary carbon isotope trend, but the $\delta^{13} \mathrm{C}_{\text {org }}$ values are slightly less depleted in ${ }^{13} \mathrm{C}$ in two episodes representing restricted lagoonal environments and in the period around the Tesero Oolite Horizon. This isotopically less depleted organic matter in the lagoons is interpreted to be most likely caused by poor oxygen ventilation and/or slightly modified salinity which may have led to restricted bioproductivity and increased hence the relative amounts of continental-sourced organic matter. In addition, elevated riverine influx and supply of terrestrial organic matter, perhaps triggered by a wet period, might be the cause for the relatively less depleted ${ }^{13} \mathrm{C}$ in the organic matter around the Tesero Oolite Horizon and in overlying sediments.
\end{abstract}

\section{Introduction}

The Palaeozoic-Mesozoic transition is marked by the severest mass extinction in Earth history which took place in the latest Permian and affected both marine and continental biota (e.g., Schindewolf 1953; Sepkoski 1989; Raup 1991; Kozur 1998a, 1998b; Jin et al., 2000; Benton \& Twitchett 2003; Erwin 2006; Peng \& Shi 2009). This event was accompanied by major perturbations in the global carbon cycle marked by a prominent negative $\delta^{13} \mathrm{C}$ excursion across the Permian-Triassic boundary (PTB) (e.g., Chen et al. 1984; Holser \& Magaritz 1987; Holser et al. 1989; Krull et al. 2000; Twitchett et al. 2001; Korte et al. 2004, 2010; Retallack et al. 2005; Algeo et al. 2007; Yin et al. 2007; Heydari et al. 2008), followed by distinct positive and negative fluctuations in the Early Triassic (e.g., Atudorei 1999; Tong et al. 2002, 2007; Payne et al. 2004; Korte et al. 2005; Galfetti et al. 2007; Horacek et al. 2007). Carbon iso- tope excursions, if global in scale, are usually traceable in carbonates and organic matter of marine and continental successions (ocean/atmosphere systems). This fact enables worldwide stratigraphic correlation of PTB successions (e.g., Cao et al. 2010; Korte \& Kozur 2010; Richoz et al. 2010) as well as for several other stage boundaries, such as the Rhaetian-Hettangian (e.g., Hesselbo et al. 2002; Korte et al. 2009; Ruhl et al. 2009) or Cenomanian-Turonian (e.g., Jarvis et al. 2006; Sageman et al. 2006).

For the PTB, parallel trends in carbonate and organic matter $\delta^{13} \mathrm{C}$ are reported for bulk organic matter and carbonate samples from some sections in the Alps and in Kashmir (e.g., Magaritz et al. 1992; Sephton et al. 2002; Algeo et al. 2007), but in other successions in Iran, Slovenia and China, deviating trends have been traced (e.g., Korte et al. 2004; Schwab \& Spangenberg 2004; Zhang et al. 2006; Riccardi et al. 2007; Yin et al. 2007). Here we study the $\delta^{13} C_{\text {carb }}$ vs $\delta^{13} C_{\text {org }}$ variations

* Corresponding author 
in a shallow marine carbonate section in the European Southern Alps in order to investigate whether the fluctuations are parallel in shallow water successions or, if not, what the potential causes are for the variations.

\section{Geological setting}

The studied section is located about $1 \mathrm{~km}$ south of Seis (Siusi) village in South Tyrol (Dolomites, Italy), in a gorge (Seiser Klamm/Gola di Siusi) along the Weissenbach River (Rio Bianco) (Fig. 1). The section comprises the Bellerophon Limestone Formation overlain by the Werfen Formation (Fig. 2). The part of the latter Formation sampled in this study consists of the Tesero Oolite Horizon (TOH) and the lower part of the Mazzin Member. The sediments were deposited on a shallow marine, restricted inner shelf on a slightly eastwardstilted carbonate ramp (Bosellini \& Hardie 1973; Noé 1987). The change from the limestone-dolomite cycles of the Bellerophon Formation to the oolites of the TOH is environmentally significant and also marks the traditional PTB (Leonardi 1967; Asserato et al. 1973). The base of the Triassic, however, is defined by the International Commission on Stratigraphy by the first appearance datum (FAD) of the conodont Hindeodus parvus (Kozur \& Pjatakova, 1976). Conodonts are rare in the Southern Alps, but Hindeodus and Isaricella occur, enabling identification of the boundary in the Pufels and Tesero sections and in the Gartnerkofel core (Perri 1991; Schönlaub 1991; Farabegoli \& Perri 1998; Nicora \& Perri 1999; Korte \& Kozur 2005; Farabegoli et al.

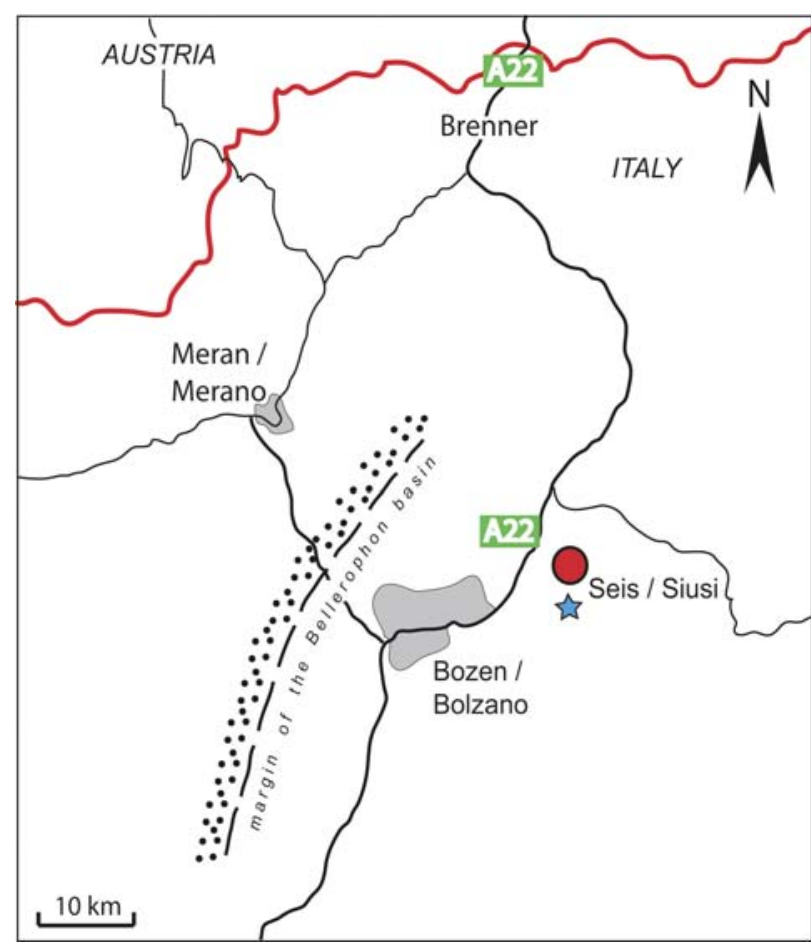

Figure 1. Sample locality in the Seiser Klamm (star) about $1 \mathrm{~km}$ south of Seis/Siusi (46 517 $\left.\mathrm{N}, 11568^{\circ} \mathrm{E}\right)$. Map modified after Brandner (1988) and Kraus et al. (2009).
2007; Posenato 2009, 2010; Korte et al. 2010). No conodont distributions are published for the Seis section. Kraus et al. (2009) discussed the chemostratigraphic PTB by using the first $\delta^{13} \mathrm{C}$ minimum (c.f., Korte \& Kozur 2010) occurring $13 \mathrm{~m}$ above the base of the TOH. In this correlation there is a lack in $\delta^{13} \mathrm{C}$ data between $6.4 \mathrm{~m}$ and $9.2 \mathrm{~m}$ (21.5 $\mathrm{m}$ and $24.3 \mathrm{~m}$ in Fig. 3). Horacek et al. (2010) subsequently published a higher resolution dataset with a carbon isotope minimum at about 8 to $8.5 \mathrm{~m}$ above the base of the TOH. We suggest, in agreement with Korte \& Kozur (2010), that this chemostratigraphic marker may represent the PTB (Figs 2-3).

During the latest Permian low-latitude main extinction event in the Tethys, a ca. $1 \%$ positive excursion (Kraus et al. 2009; Korte \& Kozur 2010; Cao et al. 2010) or a "plateau" (Richoz et al. 2010) interrupts the negative trend. Kraus et al. (2009) used this chemostratigraphic marker, starting about $0.8 \mathrm{~m}$ above the base of the TOH in the Seis section (samples 53a; Fig. 2), to define the extinction event which is most probably somewhat above (Korte \& Kozur 2010). This suggestion is in agreement with palaeontological results by Kozur (1994), but in contrast to sedimentological interpretations of the generation of the oolite or the interpretation of the disappearance of most biota which occurs at the base of the $\mathrm{TOH}$ in other western part of the Southern Alps PTB sections (Farabegoli et al. 2007; Posenato 2009). The biota, however, were affected at the base of the TOH, but fusulinids and Permian holothurian sclerites still occur in the lower Tesero Oolite Horizon (e.g., Broglio Loriga \& Cassinis 1992; Kozur 1994; Cirilli et al. 1998; Cassinis et al. 2000; Gorjan et al. 2007). Fusulinids are not found anywhere in the world above the low-latitude main extinction event and, in addition, holothurian sclerites also disappear at or even below this event, but re-appear in the Anisian (Kozur 1994, 1998a, 1998b); both observations suggest that the main extinction event was higher in the $\mathrm{TOH}$, but not at its base (Kozur 1994).

\section{Methods}

A total of 75 ca. $1.5 \mathrm{~g}$ powders were drilled from fresh surfaces of cleaned marly or micritic carbonate rocks. To avoid unwanted heating, a drill rotation of $200 \mathrm{rev} / \mathrm{min}$ was used for 5 seconds only. Approximately 100-400 microgram was filled into $10 \mathrm{ml}$ exetainers, sealed with a septum cap. After flushing with $\mathrm{He}(6 \mathrm{~min})$ and the addition of $\mathrm{H}_{3} \mathrm{PO}_{4}$, the resultant $\mathrm{CO}_{2}$ was analysed for $\delta^{13} \mathrm{C}_{\text {carb }}$ and $\delta^{18} \mathrm{O}$ on a Thermo Finnigan Gasbench II linked online to a Thermo Finnigan Delta V mass spectrometer in the stable isotope laboratory of the $\mathrm{Mu}-$ seum für Naturkunde in Berlin. The reproducibility of replicated standards was better than $0.1 \%$ (one standard deviation) for carbon- and oxygen-isotopes. The $\delta^{13} \mathrm{C}$ and $\delta^{18} \mathrm{O}$ values were calibrated against $\mathrm{V}$ PDB and are reported in the standard \%o-notation (Table 1). Residual

Figure 2. Lithology and sample locations of the Seis/Siusi section. 


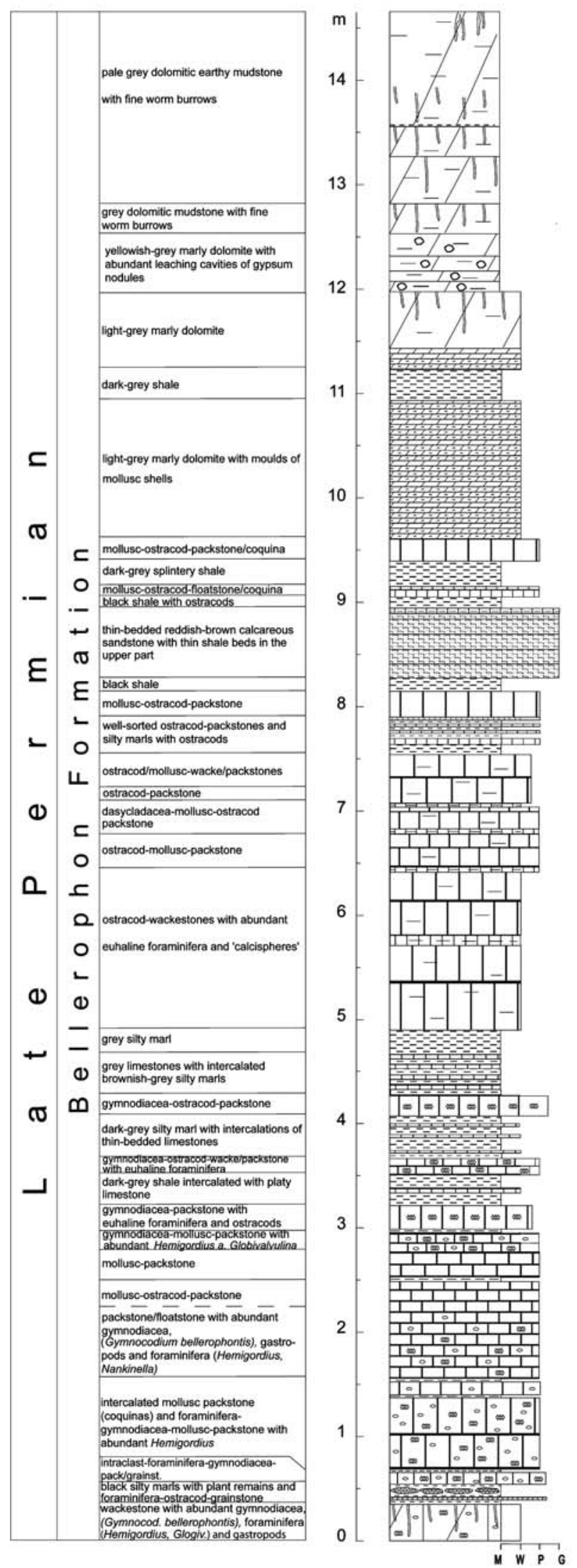

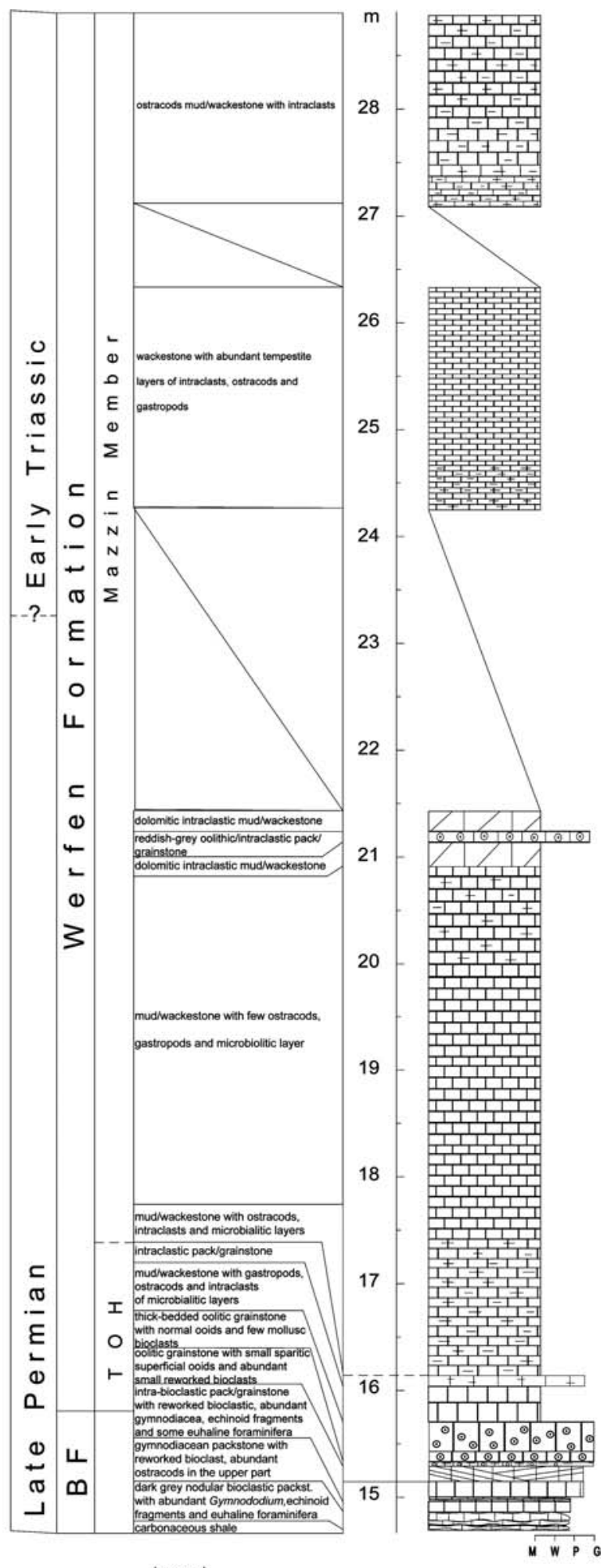

Legend:

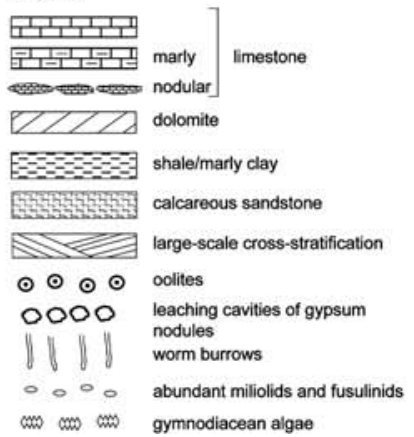



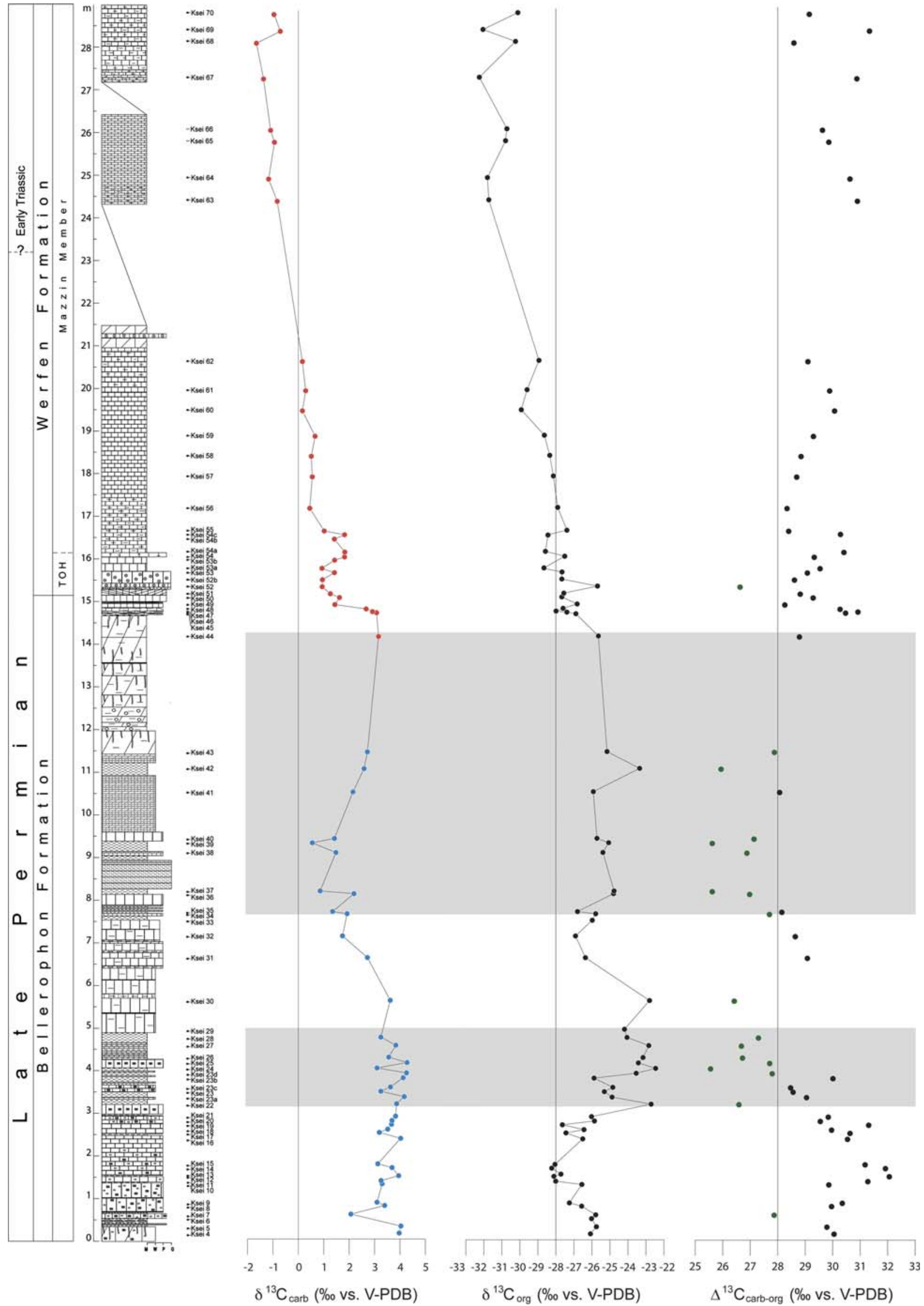

Figure 3. Carbon isotope values for bulk carbonates and organic matter and $\delta^{13} \mathrm{C}$ of the Seis/Siusi section (the corrected scale deviates now slightly from Kraus et al. 2009). 
Table 1. Stable isotope and TOC values of investigated samples.

\begin{tabular}{|c|c|c|c|c|c|c|c|c|c|}
\hline Sample & $\begin{array}{l}\delta^{13} C_{\text {carb }} \text { vs. } \\
\text { V-PDB [\%॰] }\end{array}$ & $\begin{array}{l}\delta^{13} C_{\text {org }} \text { vs. } \\
\text { V-PDB [\%०] }\end{array}$ & $\begin{array}{l}\text { TOC } \\
{[\%]}\end{array}$ & $\begin{array}{l}\delta^{18} \mathrm{O} \text { vs. } \\
\text { V-SMOW [\%०] }\end{array}$ & Sample & $\begin{array}{l}\delta^{13} C_{c a r b} \text { vs. } \\
\text { V-PDB [\%०] }\end{array}$ & $\begin{array}{l}\delta^{13} C_{o r g} \text { vs. } \\
\text { V-PDB [\%॰] }\end{array}$ & $\begin{array}{l}\text { TOC } \\
{[\%]}\end{array}$ & $\begin{array}{l}\delta^{18} \mathrm{O} \text { vs. } \\
\text { V-SMOW [\%०] }\end{array}$ \\
\hline Ksei 4 & 3.97 & -26.08 & & 23.07 & Ksei 38 & 1.48 & -25.39 & & 25.76 \\
\hline Ksei 5 & 4.04 & -25.75 & & 25.02 & Ksei 39 & 0.55 & -25.07 & & 25.58 \\
\hline Ksei 6 & & -26.02 & & & Ksei 40 & 1.42 & -25.72 & & 26.59 \\
\hline Ksei 7 & 2.07 & -25.79 & & 23.35 & Ksei 41 & 2.15 & -25.92 & & 29.51 \\
\hline Ksei 8 & 3.40 & -26.57 & & 23.93 & Ksei 42 & 2.59 & -23.35 & & 26.75 \\
\hline Ksei 9 & 3.10 & -27.25 & & 22.79 & Ksei 43 & 2.72 & -25.16 & & 25.69 \\
\hline Ksei 10 & 3.30 & -26.56 & & 23.03 & Ksei 44 & & -25.64 & & \\
\hline Ksei 11 & 3.26 & -28.01 & & 24.88 & Ksei 45 & & -26.89 & & \\
\hline Ksei 12 & 3.95 & -28.11 & & 25.28 & Ksei 46 & & -27.39 & & \\
\hline Ksei 13 & & -27.72 & & & Ksei 47 & & -27.99 & & \\
\hline Ksei 14 & 3.69 & -28.23 & & 24.88 & Ksei 48 & & -27.60 & & \\
\hline Ksei 15 & 3.13 & -28.05 & & 23.69 & Ksei 49 & & -26.82 & & \\
\hline Ksei 16 & 4.03 & -26.51 & & 22.64 & Ksei 50 & & -27.67 & & \\
\hline Ksei 17 & 3.19 & -27.44 & & 23.34 & Ksei 51 & & -27.56 & & \\
\hline Ksei 18 & 3.52 & -26.44 & & 25.49 & Ksei 52 & & -25.69 & & \\
\hline Ksei 19 & 3.67 & -27.64 & & 24.51 & Ksei 52b & & -27.67 & 0.09 & \\
\hline Ksei 20 & 3.69 & -25.86 & & 23.94 & Ksei 53 & & -27.66 & & \\
\hline Ksei 21 & 3.83 & -26.02 & & 26.44 & Ksei 53a & & -28.73 & 0.02 & \\
\hline Ksei 22 & 3.87 & -22.71 & & 24.68 & Ksei 54 & & -27.51 & & \\
\hline Ksei 23a & 4.17 & -24.88 & & 25.85 & Ksei 54a & & -28.58 & 0.02 & \\
\hline Ksei 23 & 3.25 & -25.31 & & 24.24 & Ksei 54c & & -28.43 & 0.05 & \\
\hline Ksei 23c & 3.63 & -24.84 & & 25.56 & Ksei 55 & & -27.39 & & \\
\hline Ksei 23b & 4.13 & -25.88 & & 25.37 & Ksei 56 & & -27.90 & & \\
\hline Ksei 23d & 4.26 & -23.54 & & 26.42 & Ksei 57 & & -28.14 & & \\
\hline Ksei 24 & 3.10 & -22.46 & & 24.98 & Ksei 58 & & -28.34 & & \\
\hline Ksei 25 & 4.28 & -23.42 & & 26.15 & Ksei 59 & & -28.64 & & \\
\hline Ksei 26 & 3.56 & -23.16 & & 25.25 & Ksei 60 & & -29.92 & & \\
\hline Ksei 27 & 3.84 & -22.84 & & 25.73 & Ksei 61 & & -29.60 & & \\
\hline Ksei 28 & 3.25 & -24.05 & & 26.27 & Ksei 62 & & -28.94 & & \\
\hline Ksei 29 & & -24.19 & & & Ksei 63 & & -31.73 & 0.01 & \\
\hline Ksei 30 & 3.62 & -22.80 & & 25.09 & Ksei 64 & & -31.80 & 0.08 & \\
\hline Ksei 31 & 2.72 & -26.36 & & 24.65 & Ksei 65 & & -30.80 & 0.05 & \\
\hline Ksei 32 & 1.74 & -26.91 & & 25.47 & Ksei 66 & & -30.72 & 0.03 & \\
\hline Ksei 33 & & -25.98 & & & Ksei 67 & & -32.25 & 0.07 & \\
\hline Ksei 34 & 1.92 & -25.79 & & 24.78 & Ksei 68 & & -30.24 & 0.05 & \\
\hline Ksei 35 & 1.35 & -26.80 & & 25.11 & Ksei 69 & & -32.05 & 0.09 & \\
\hline Ksei 36 & 2.19 & -24.80 & & 25.86 & Ksei 70 & & -30.11 & 0.04 & \\
\hline Ksei 37 & 0.86 & -24.77 & & 25.06 & & & & & \\
\hline
\end{tabular}

sample powder was decarbonated using $2 \mathrm{M}$ hydrochloric acid, followed by a repeated neutralisation treatment consisting of $\mathrm{H}_{2} \mathrm{O}_{\text {dest }}$ rinse, centrifugation and decantation. The samples were dried at $40{ }^{\circ} \mathrm{C}$ for 48 hours. About $30 \mathrm{mg}$ of each of these samples were packed into tin capsules and $\delta^{13} \mathrm{C}_{\text {org }}$ and total organic carbon (TOC) was measured subsequently using a THERMO/Finnigan MAT V isotope ratio mass spectrometer, coupled to a THERMO Flash EA 1112 elemental analyzer via a THERMO/Finnigan Conflo III- interface in the stable isotope laboratory of the Museum für Naturkunde, Berlin (Table 1). Stable isotope ratios were expressed in the conventional delta notation relative to VPDB. The standard deviation for repeated measurements of lab standard material (peptone) was better than $0.15 \%$.

\section{Results}

The $\delta^{13} \mathrm{C}_{\text {carb }}$ values (Fig. 3) from the Seis section, including data from Kraus et al. (2009), vary between +3 and $+4 \%$ in the lower Bellerophon Formation (sample 4 to 30 ), decrease to +1 to $+2 \%$ (sample 31 to 41 ) and return to $\sim+3 \%$ (sample 42 to 47 ) in the middle Bellerophon Formation. Above this level, $\delta^{13} \mathrm{C}_{\text {carb }}$ values decrease subsequently, interrupted by a characteristic $1 \%$ positive excursion at $0.8 \mathrm{~m}$ above 


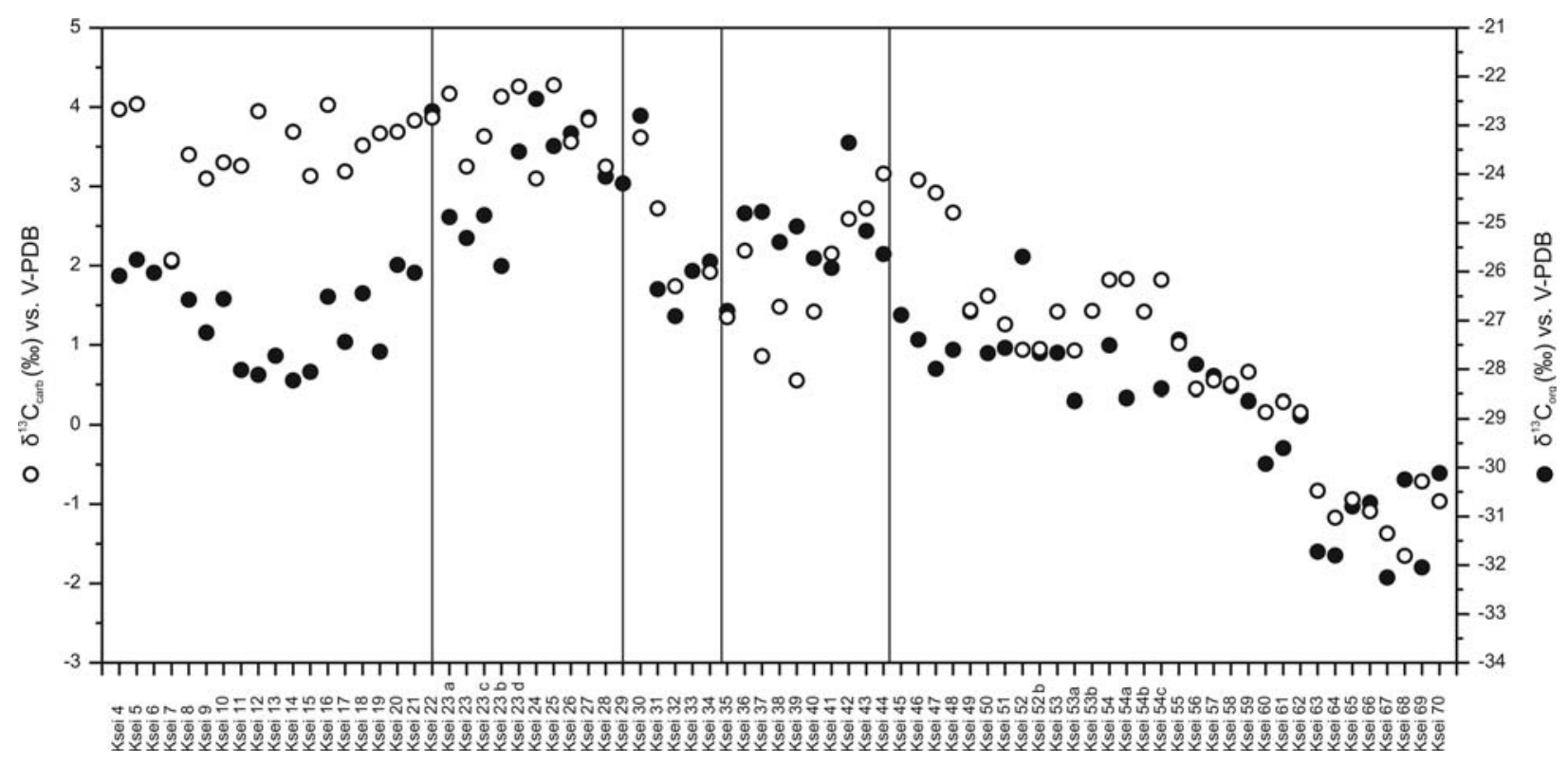

Figure 4. Comparison of $\delta^{13} \mathrm{C}_{\text {carb }}$ and $\delta^{13} \mathrm{C}_{\text {org }}$ trends of the Seis/Siusi section.

the base of the TOH (Kraus et al. 2009; Korte \& Kozur $2010)$, to values of about $+1.5 \%$ in the lowermost Mazzin Member.

The organic matter carbon isotope values vary by about $10 \%$ o (Figs $3-4$ ) from $\sim-22 \%$ to $\sim-32 \%$. The values decrease from $\sim-26 \%$ to $\sim-28 \%$ between samples 4 and 14, increase gradually to $\sim-22 \%$ towards sample 24 , decrease again to $\sim-27 \%$ at sample 32 , then increase to $\sim-23.5 \%$ at sample 42 , and finally decrease gradually to $\sim-32 \%$ towards the top of the sections.

The $\delta^{13} \mathrm{C}$ signatures of carbonates and organic matter show in general similar, long-lasting negative trends across the PTB. It is further clear that the organic matter carbon isotopes, in comparison to the carbonate carbon isotopes, are less depleted in ${ }^{13} \mathrm{C}$ in the three parts of the section between samples 22 and 29, between samples 34 and 44 (grey shadows in Figure 3), and around the TOH (Figs 3, 4). The TOC concentrations of the carbonates from the Seis section, determined for 12 samples only, are low and range from 0.01 to $0.09 \%$ (Table 1).

\section{Discussion}

Several hypotheses have been proposed to explain the initiation of the negative $\delta^{13} \mathrm{C}$ excursion at the PTB. The most prominent are a global drop in sea-level (e.g., Holser \& Magaritz 1987; Baud et al. 1989), a decrease in primary productivity (e.g., Magaritz 1989; Visscher et al. 1996), the release of methane from the seafloor, permafrost soils and/or heated coals (e.g., Erwin 1994; Krull \& Retallack 2000), an oceanic overturn or an upwards rise of anoxic waters (e.g., Malkowski et al. 1989; Knoll et al. 1996; Kump et al. 2005; Riccardi et al. 2007) and burning or metamorphism of organics by Siberian Trap sills and dykes when intruded into sediments (e.g., Payne \& Kump 2007; Svensen et al. 2009; Korte et al. 2010). Many authors assume that a combination of various factors were presumably responsible (e.g., Berner 2002; Sephton et al. 2005; Corsetti et al. 2005; Retallack \& Jahren 2008; Korte et al. 2010). Additional information about the causes of the PTB negative excursion can be interpreted from the carbon isotope trends at Seis.

The carbonate carbon isotope trend in the Seis section is similar to those of other Southern Alps sections (e.g., Magaritz et al. 1988; Holser et al. 1989; Oberhänsli et al. 1989; Korte \& Kozur 2005; Horacek et al. 2007, 2010; Kraus et al. 2009; Korte et al. 2010) and to the general carbon isotope trend across the PTB as suggested by Korte \& Kozur (2010). We therefore propose that deviations of the $\delta^{13} C_{\text {org }}$ record need extra explanation(s). The $\delta^{13} \mathrm{C}$ trends of marine carbonates and organic matter should show the same trends because their carbon originates from the same source, the marine-dissolved carbon reservoir. It should be emphasized that the measured TOC values in the higher part of the Seis succession are very low and even slight secondary effects could have altered significantly the bulk rock $\delta^{13} \mathrm{C}_{\text {org. }}$. The deviant isotope trends in organic carbon reported for the Bellerophon Formation (Fig. 3) are particularly prone to impregnation by migrating hydrocarbon fluids because of the high permeability of these limestones (Schwark, personal communication 2011). While a future organic geochemical characterisation of the Seis sections is a desirable, the carbon isotope signature of any migrated petroleum would be light, opposite to the observed deviations in the Bellerophon Formation (Fig. 3). It is therefore likely that the deviating trends are primary in origin.

Parallel trends of $\delta^{13} C_{\text {carb }}$ and $\delta^{13} C_{\text {org }}$ were reported for the Gartnerkofel core and the Misci (Seres) section 
in the Southern Alps (Magaritz et al. 1992; Sephton et al. 2002), but both datasets do not allow precise observations because of their low resolution, especially above the top of the Bellerophon Limestone Formation. Opposing trends in carbon isotopes of carbonates and organics occur in the Idrijca Valley section in Western Slovenia (Schwab \& Spangenberg 2004; see also Dolenec et al. 2001). Deviating $\delta^{13} C_{\text {org }}$ values with regard to carbonate carbon isotopes might be caused by heterogeneous sources of the organics (marine/terrestrial/bacterial) (see e.g., Deines 1980; Whiticar 1996). For instance, Permian wood shows heavier carbon isotope values than coeval marine organic matter (Faure et al. 1995; Foster et al. 1997; Korte et al. 2001). Changes in the amount of terrestrial organic matter in marine sediments probably impacted the negative carbon-isotope shift in Australian PTB successions (Morante 1996; Foster et al. 1997; Thomas et al. 2004). To complicate matters, ocean anoxia was widespread in the latest Permian oceans (e.g., Wignall \& Hallam 1992; Kajiwara et al. 1994; Isozaki 1997; Algeo et al. 2008; Grasby \& Beauchamp 2009) reaching even shallow water depths, as traced by green sulphur bacteria (= Chlorobiaceae) in the PTB Hovea-3 core from W-Australia (Grice et al. 2005). Chlorobiaceae are using $\mathrm{H}_{2} \mathrm{~S}$ and $\mathrm{CO}^{2}$ in the photic zone for their anaerobic photosynthesis and do not discriminate as strongly against ${ }^{13} \mathrm{C}$ as in the $\mathrm{C}^{3}$-pathway (Sirevag et al. 1977). The resulting biomass might therefore be heavier (although this is dependent on the $\delta^{13} \mathrm{C}$ of the anoxic waters which can be already depleted in ${ }^{13} \mathrm{C}$ ) compared to marine organic matter that is produced coevally in oxygenated seawater (Summons $\&$ Powell 1986). The use of bulk $\delta^{13} C_{\text {org }}$ values for stratigraphic correlation purposes across the PTB might be therefore difficult (Riccardi et al. 2007).

The first two sedimentary units at the Seis section characterized by relative ${ }^{13} \mathrm{C}$-enriched (compared to $\delta^{13} \mathrm{C}_{\text {carb}}$ ) organic carbon isotopes (grey shadows in Figure 3; samples 22 to 29 and 34 to 44; see also Figure 4) are interpreted to have been deposited in enclosed lagoons with low oxygen concentrations and/or reduced salinity, indicated by low diverse ostracod assemblages dominated by species of Cavellina and Sargentina. In these restricted palaeoenvironments, euhaline conditions would have likely occurred periodically, as indicted by a more diverse faunas with euhaline ostracods in sample 24. Diverse ostracod assemblages of large and thickshelled Paraparchitidae above sample 30 point to a typical high-energy environment (beach and foreshore area) and confirm microfacies interpretations of an open lagoon environment here. A second restricted lagoon environment commences above sample 33. Here, poorly oxygenated conditions and/or slightly modified salinity can be interpreted based again on a low diverse ostracod fauna. The water in this lagoon was mixed occasionally because slightly more diverse faunas (some euhaline species with few individuals) occur in samples 35 and 38 suggesting that normal marine conditions existed temporarily. All these observations suggest that low oxygen concentrations occurred during the two periods of restricted lagoonal conditions in the Late Permian Bellerophon Limestone Formation (grey shadow in Figure 3) at Seis. It is therefore possible that the $\delta^{13} \mathrm{C}_{\text {org }}$ values might have been influenced occasionally by anoxic conditions (see above). However, an additional factor may have been more important in affecting carbon isotopic compositions. During the first restricted lagoonal period, enrichments in phytoclasts (coalified wood and other plant remains; Fig. 2) are indicative of a strongly enhanced influx of terrestrial organic matter and suggesting that this was the factor most responsible for the pronounced relative ${ }^{13} \mathrm{C}$-enriched organic carbon isotope signature in the lower grey shaded section of Figures 3 and 4 (heavier $\delta^{13} \mathrm{C}$ of terrestrial versus marine-sourced organic matter; see above and $\delta^{13} \mathrm{C}$ in Figure 3). A stronger influx of terrestrial organic matter in the second interval of restricted lagoonal facies cannot be confirmed by macroscopic investigations and here a geochemical characterization of the organic matter is desirable to verify this hypothesis.

The relative ${ }^{13} \mathrm{C}$ enriched organic matter (compared to $\delta^{13} \mathrm{C}_{\text {carb }}$ ) around the TOH in Seis (Fig. 4) is more difficult to evaluate because fossils are rare or absent and the origin of the $\mathrm{TOH}$ is still in discussion (see above). Information can be taken from organic geochemistry results from the Idrijca Valley section which was deposited more distally on the same carbonate ramp as the Southern Alps succession. A similar carbon isotope deviation has been reported here for practically the same stratigraphic level (Schwab \& Spangenberg 2004). Relative ${ }^{13} \mathrm{C}$ enriched organic matter occurs ca. $1 \mathrm{~m}$ below the top of the Žažar Formation, a stratigraphic level that is characterised by a gradual decrease in $\delta^{13} \mathrm{C}_{\text {carb. }}$ This period of deviating carbonate vs. organic $\delta^{13} \mathrm{C}$ was developed under oxygenated conditions (Schwab \& Spangenberg 2004) suggesting that the differing trends here were not caused by anoxia. In contrast, a contribution of organic matter from land plants is evident for the Idrijca Valley section (Schwab \& Spangenberg 2004) and, in addition, also for the Misci (Seres) section in the Southern Alps (Sephton et al. 2001; Watson et al. 2005) and for the Rizvanuša and Brezimenjača successions in Croatia (Fio et al. 2010) at this time, thus supporting the suggestion that enhanced terrestrial influx around the TOH at Seis has produced the ${ }^{13} \mathrm{C}$-enriched organic matter.

Elevated influx of continental-sourced carbon around the $\mathrm{TOH}$ is consistent with other geological data. At this time an episode of elevated freshwater influx into the seas occurred, suggested to be the result of a pluvial event starting near the low-latitude marine event horizon (Kozur 1998a, 1998b; Krassilov \& Karasev 2009; Korte \& Kozur 2011; see also Sephton et al. 2005). This wet interval was probably not only restricted to the Southern Alps and Hungary, but does occur also in the Germanic Basin were hypersaline sabkha sediments are overlain by fluvial and fresh water lake deposits and in marginal development the water energy of rivers was 
distinctly elevated. In addition, it has been shown that the water energy of discharging rivers in Australia (Michaelsen 2002), South Africa (Ward et al. 2000), Northern Alps (Kozur 1998a, 1998b) and Russia (Newell et al. 1999) was distinctly elevated, consistent with a global period of elevated rainfall. An exact stratigraphic correlation of the latter four areas with the Germanic Basin, however, is difficult.

\section{Summary}

In three parts of the Seis/Siusi section, represented by two restricted lagoons in the Bellerophon Limestone Formation and in the period around the Tesero Oolite Horizon, the $\delta^{13} \mathrm{C}_{\text {org }}$ values are less depleted in ${ }^{13} \mathrm{C}$ (compared to coeval $\delta^{13} \mathrm{C}_{\mathrm{carb}}$ ) than in the remainder of the carbonate succession. These less depleted ${ }^{13} \mathrm{C}$ values are probably caused by the restricted nature of lagoons with a higher influx of terrestrial organic matter combined with low oxygen levels and occasionally anoxia effects and/or lower bioproductivity. Enhanced riverine influx around the Tesero Oolite Horizon (starting somewhat below its base and persisted somewhat upsection) might have supplied elevated terrestrial organic matter due to a wet phase (pluvial event).

\section{Acknowledgements}

We acknowledge E. Kuhl (Berlin) for technical assistance, H. W. Kozur (Budapest) and L. Schwark (Kiel) for the reviews and pertinent comments, T. E. Waight (Copenhagen) for discussion and English corrections and the Freie Universität Berlin for contributions to financing this project and for providing the necessary facilities.

\section{Literature}

Algeo, T. J., Hannigan, R., Rowe, H., Brookfield, M., Baud, A., Krystyn, L. \& Ellwood, B. B. 2007. Sequencing events across the Permian-Triassic boundary, Guryul Ravine (Kashmir, India). - Palaeogeography, Palaeoclimatology, Palaeoecology 252: 328-346.

Algeo, T., Shen, Yanan, Zhang, Tonggang, Lyons, T., Bates, S., Rowe, H. \& Nguyen, T. K. T. 2008. Association of ${ }^{34} \mathrm{~S}$-depleted pyrite layers with negative carbonate $\delta^{13} \mathrm{C}$ excursions at the Permian-Triassic boundary: Evidence for upwelling of sulfidic deep-ocean water masses. - Geochemistry Geophysics Geosystems 9: Q04025, doi:10.1029/2007GC001823.

Assereto, R., Bosellini, A., Fantini Sestini, N. \& Sweet, W. C. 1973. The Permian-Triassic boundary in the Southern Alps (Italy). In Logan, A. \& Hills, V. (eds). The Permian and Triassic Systems and their Mutual Boundary. - Canadian Society of Petroleum Geologists Memoir 2: 176-199.

Atudorei, N.-V. 1999. Constraints on the Upper Permian to Upper Triassic marine carbon isotope curve. Case studies from the Tethys. Ph.D. thesis, University of Lausanne.

Baud, A., Magaritz, M. \& Holser, W. T. 1989. Permian-Triassic of the Tethys: Carbon isotope studies. - Geologische Rundschau 78: 649-677.

Benton, M. J. \& Twitchett, R. J. 2003. How to kill (almost) all life: the end-Permian extinction event. - Trends in Ecology and Evolution 18: 358-365.
Berner, R. A. 2002. Examination of hypotheses for the Permo-Triassic boundary extinction by carbon cycle modeling. - Proceedings of National Academic Science of the United States of America 99: 4172-4177.

Bosellini, A. \& Hardie, A. L. 1973. Depositional theme of a marginal marine evaporite. - Sedimentology 20: 5-27.

Brandner, R. 1988. The Permian-Triassic boundary in the Dolomites (Southern Alps, Italy), San Antonio section. IGCP-Project 199: „Rare events in geology“. - Berichte der Geologischen Bundesanstalt 15: 49-56.

Broglio Loriga, C. \& Cassinis, G. 1992. The Permo-Triassic boundary in the Southern Alps (Italy) and in adjacent Periadriatic regions. In Sweet W. C., Yang, Zun-yi, Dickins J. M. \& Yin, Hong-fu (eds). Permo-Triassic Events in the Eastern Tethys. Cambridge University Press, Cambridge: pp. 78-97.

Cao, C.-Q., Yang, Y.-C., Shen, S.-Z., Wang, W., Zheng, Q.-F. \& Summons, R. E. 2010. Pattern of $\delta^{13} C_{\text {carb }}$ and implications for geological events during the Permian-Triassic transition in South China. - Geological Journal 45: 186-194.

Cassinis, G., Di Stefano, P., Massari, F., Neri, C. \& Venturini, C. 2000. Permian of South Europe and its interregional correlation. In Yin Hong-fu, Dickins, J.-M., Shi, G.-R. \& Tong, Jin-nan (eds). Permian-Triassic evolution of Tethys and western circum-Pacific. Elsevier, Amsterdam: pp. 37-70.

Chen Jin-shi, Shao Mao-rong, Huo Wei-guo \& Yao Yu-yuan. 1984. Carbon isotope of carbonate strata at Permian-Triassic boundary in Changxing, Zhejiang. - Scientia Geologica Sinica 19 (1): 8893 [in Chinese with English abstract].

Cirilli, S., Pirini Radrizzani, C., Ponton, M. \& Radrizzani, S. 1998. Stratigraphical and palaeoenvironmental analysis of the PermianTriassic transition in the Badia Valley (Southern Alps, Italy). Palaeogeography, Palaeoclimatology, Palaeoecology 138: 85-113.

Corsetti, F. A., Baud, A., Marenco, P. J. \& Richoz, S. 2005. Summary of Early Triassic carbon isotope records. - Comptes Rendus Palevol 4: 473-486.

Deines, P. 1980. The isotopic composition of reduced organic carbon. In Fritz, P. \& Fontes, J. C. (eds). Handbook of environmental isotope geochemistry. Vol. 1: The terrestrial environment, A. Elsevier, Amsterdam: pp. 329-406.

Dolenec, T., Lojen, S. \& Ramovš, A. 2001. The Permian-Triassic boundary in Western Slovenia (Idrijca Valley section): Magnetostratigraphy, stable isotopes, and elemental variations. - Chemical Geology 175: 175-190.

Erwin, D. H. 1994. The Permo-Triassic extinction. - Nature 367: 231-236.

Erwin, D. H. 2006. Extinction - How life on Earth nearly ended 250 million years ago. Princeton University Press, Princeton and Oxford.

Farabegoli, E. \& Perri, M. C. 1998. Stop 4.3 - Permian/Triassic boundary and Early Triassic of the Bulla section (Southern Alps, Italy): Lithostratigraphy, facies and conodont biostratigraphy. Giornale di Geologia Ser. $3^{\mathrm{a}}$ (special issue, ECOS VII Southern Alps Fieldtrip Guidebook) 60: 292-311.

Farabegoli, E., Perri, M. C. \& Posenato, R. 2007. Environmental and biotic changes across the Permian-Triassic boundary in western Tethys: The Bulla parastratotype, Italy. - Global and Planetary Change 55: 109-135.

Faure, K., de Wit, M. J. \& Willis, J. P. 1995. Late Permian global coal hiatus linked to ${ }^{13} \mathrm{C}$-depleted $\mathrm{CO}_{2}$ flux into the atmosphere during the final consolidation of Pangea. - Geology 23: 507-510.

Fio, K., Spangenberg, J. E., Vlahović, I., Sremac, J., Velić, I. \& Mrinjek, E. 2010. Stable isotope and trace element stratigraphy across the Permian-Triassic transition: A redefinition of the boundary in the Velebit Mountain, Croatia. - Chemical Geology 278: 38-57.

Foster, C. B., Logan, G. A., Summons, R. E., Gorter, J. D. \& Edwards, D. S. 1997. Carbon isotopes, kerogen types and the Permian-Triassic boundary in Australia: Implications for exploration. - Australian Petroleum Production and Exploration Association Journal 37: 472-489. 
Galfetti, T., Bucher, H., Brayard, A., Hochuli, P. A., Weissert, H., Guodun, K., Atudorei, V. \& Guex, J. 2007. Late Early Triassic climate change: Insights from carbonate carbon isotopes, sedimentary evolution and ammonoid paleobiogeography. - Palaeogeography, Palaeoclimatology, Palaeoecology 243: 394-411.

Gorjan, P., Kaiho, K., Kakegawa, T., Niitsuma, S., Chen, Z.-Q., Kajiwara, Y. \& Nicora, A. 2007. Paleoredox, biotic and sulfur-isotopic changes associated with the end-Permian mass extinction in the western Tethys. - Chemical Geology 244: 483-492.

Grasby, S. E. \& Beauchamp, B. 2009. Latest Permian to Early Triassic basin-to-shelf anoxia in the Sverdrup Basin, Arctic Canada. Chemical Geology 264: 232-246.

Grice, K., Cao Chang-qun, Love, G. D., Böttcher, M. E., Twitchett, R. J., Grosjean, E., Summons, R. E., Turgeon, S. C., Dunning, W. \& Jin Yu-gan. 2005. Photic zone euxinia during the Permian-Triassic superanoxic event. - Science 307: 706-709

Hesselbo, S. P., Robinson, S. A., Surlyk, F. \& Piasecki, S. 2002. Terrestrial and marine extinction at the Triassic-Jurassic boundary synchronized with major carbon-cycle perturbation: A link to initiation of massive volcanism? - Geology 30: 251-254.

Heydari, E., Arzani, N. \& Hassanzadeh, J. 2008. Mantle plume: The invisible serial killer - Application to the Permian-Triassic boundary mass extinction. - Palaeogeography, Palaeoclimatology, Palaeoecology 264: 147-162.

Holser, W. T. \& Magaritz, M. 1987. Events near the Permian-Triassic boundary. - Modern Geology 11: 155-180.

Holser, W. T., Schönlaub, H.-P., Attrep, M., Boeckelmann, K., Klein, P., Magaritz, M., Orth, C. J., Fenninger, A., Jenny, C., Kralik, M., Mauritsch, H., Pak, E., Schramm, J.-M., Stattegger, K. \& Schmöller, R. 1989. A unique geochemical record at the Permian/Triassic boundary. - Nature 337: 39-44.

Horacek, M., Brandner, R. \& Abart, R. 2007. Carbon isotope record of the P/T boundary and the Lower Triassic in the Southern Alps: Evidence for rapid changes in storage of organic carbon. - Palaeogeography, Palaeoclimatology, Palaeoecology 252: 347-354.

Horacek, M., Povoden, E., Richoz, S. \& Brandner, R. 2010. Highresolution carbon isotope changes, litho- and magnetostratigraphy across Permian-Triassic boundary sections in the Dolomites, NItaly. New constraints for global correlation. - Palaeogeography, Palaeoclimatology, Palaeoecology 290: 58-64.

Isozaki, Y. 1997. Permo-Triassic boundary superanoxia and stratified superocean: records from lost deep-sea. - Science 276: 235-238.

Jarvis, I., Gale, A. S., Jenkyns, H. C. \& Pearce, M. A. 2006. Secular variation in Late Cretaceous carbon isotopes: a new $\delta^{13} \mathrm{C}$ carbonate reference curve for the Cenomanian-Campanian (99.670.6 Ma). - Geological Magazine 143: 561-608.

Jin Yu-gan, Wang Yue, Wang Wei, Shang Qing-hua, Cao Chang-qun \& Erwin, D. H. 2000. Pattern of marine mass extinction near the Permian-Triassic boundary in South China. - Science 289: 432-436.

Kajiwara, Y., Yamakita, S., Ishida, K., Ishiga, H. \& Imai, A. 1994. Development of a largely anoxic stratified ocean and its temporary massive mixing at the Permian/Triassic boundary supported by the sulfur isotopic record. - Palaeogeography, Palaeoclimatology, Palaeoecology 111: 367-379.

Knoll, A. H., Bambach, R. K., Canfield, D. E. \& Grotzinger, J. P. 1996. Comparative Earth history and late Permian mass extinction. - Science 273: 452-457.

Korte, C. \& Kozur, H. W. 2005. Carbon isotope stratigraphy across the Permian/Triassic boundary at Jolfa (NW-Iran), Peitlerkofel (Sas de Pütia, Sass de Putia), Pufels (Bula, Bulla), Tesero (all three Southern Alps, Italy) and Gerennavár (Bükk Mts., Hungary). - Journal of Alpine Geology 47: 119-135.

Korte, C. \& Kozur, H. W. 2010. Carbon isotope stratigraphy across the Permian-Triassic boundary: A review. - Journal of Asian Earth Sciences 39: 215-235.

Korte, C. \& Kozur, H. W. 2011 in press. Temperature changes across the Permian-Triassic boundary and observations pertaining to some geological/geochemical features around this level. In Bhargava, O. N. (ed.). Facets of Phanerozoic. Memoir Geological Society of India, Bangalore.

Korte, C., Veizer, J., Leythaeuser, D., Below, R. \& Schwark, L. 2001. Evolution of Permian and Lower Triassic $\delta^{13} \mathrm{C}$ in marine and terrigenous organic material. - Terra Nostra 2001 (4): 30-34.

Korte, C., Kozur, H. W., Joachimski, M. M., Strauss, H., Veizer, J. \& Schwark, L. 2004. Carbon, sulfur, oxygen and strontium isotope records, organic geochemistry and biostratigraphy across the Permian/Triassic boundary in Abadeh, Iran. - International Journal of Earth Sciences 93: 565-581.

Korte, C., Kozur, H. W. \& Veizer, J. 2005. $\delta^{13} \mathrm{C}$ and $\delta^{18} \mathrm{O}$ values of Triassic brachiopods and carbonate rocks as proxies for coeval seawater and palaeotemperature. - Palaeogeography, Palaeoclimatology, Palaeoecology 226: 287-306.

Korte, C., Hesselbo, S. P., Jenkyns, H. C., Rickaby, R. E. M. \& Spötl, C. 2009. Palaeoenvironmental significance of carbon- and oxygen-isotope stratigraphy of marine Triassic-Jurassic boundary sections in SW Britain. - Journal of the Geological Society, London 166: 431-445.

Korte, C., Pande, P., Kalia, P., Kozur, H. W., Joachimski, M. M. \& Oberhänsli, H. 2010. Massive volcanism at the Permian-Triassic boundary and its impact on the isotopic composition of the ocean and atmosphere. - Journal of Asian Earth Sciences 37: 293-311.

Kozur, H. W. 1994. The correlation of the Zechstein with the marine standard. - Jahrbuch der Geologischen Bundesanstalt 137: 85103.

Kozur, H. W. 1998a. Some aspects of the Permian-Triassic boundary (PTB) and of the possible causes for the biotic crisis around this boundary. - Palaeogeography, Palaeoclimatology, Palaeoecology 143: $227-272$.

Kozur, H. W. 1998b. Problems for evaluation of the scenario of the Permian-Triassic boundary biotic crisis and of its causes. - Geologia Croatica 51/2: 135-162.

Kozur, H. W. \& Pjatakova, M. 1976. Die Conodontenart Anchignathodus parvus n. sp., eine wichtige Leitform der basalen Trias. Proceedings of the Koninklijke Nederlandse Akademie van Wetenschappen, Series B 79 (2): 123-128.

Krassilov, V. \& Karasev, E. 2009. Paleofloristic evidence of climate change near and beyond the Permian-Triassic boundary. - Palaeogeography, Palaeoclimatology, Palaeoecology 284: 326-336.

Kraus, S. H., Siegert, S., Mette, W., Struck, U. \& Korte, C. 2009. Stratigraphic significance of carbon isotope variations in the shallow-marine Seis/Siusi Permian-Triassic boundary section (Southern Alps, Italy). - Fossil Record 12 (2): 197-205.

Krull, E. S. \& Retallack, G. J. 2000. $\delta^{13} \mathrm{C}$ depth profiles from paleosols across the Permian-Triassic boundary: Evidence for methane release. - Geological Society of America Bulletin 112: 14591472.

Krull, E. S., Retallack, G. J., Campbell, H. J. \& Lyon, G. L. 2000 $\delta^{13} \mathrm{C}_{\text {org }}$ chemostratigraphy of the Permian-Triassic boundary in the Maitai Group, New Zealand: Evidence for high-latitudinal methane release. - New Zealand Journal of Geology and Geophysics 43: $21-32$.

Kump, L. R., Pavlov, A. \& Arthur, M. A. 2005. Massive release of hydrogen sulfide to the surface ocean and atmosphere during intervals of oceanic anoxia. - Geology 33: 397-400.

Leonardi, P. 1967. Le Dolomiti. Geologia dei monti tra Isarco e Piave. 3 volumi. R. Manfrini, Rovereto.

Magaritz, M. 1989. ${ }^{13} \mathrm{C}$ minima follow extinction events: A clue to faunal radiation. - Geology 17: 337-340.

Magaritz, M., Bär, R., Baud, A. \& Holser, W. T. 1988. The carbonisotope shift at the Permian/Triassic boundary in the Southern Alps is gradual. - Nature 331: 337-339.

Magaritz, M., Krishnamurthy, R. V. \& Holser, W. T. 1992. Parallel trends in organic and inorganic carbon isotopes across the Permian/ Triassic boundary. - American Journal of Science 292: 727-739. 
Malkowski, K., Gruszczynski, M., Hoffman, A. \& Halas, S. 1989. Oceanic stable isotope composition and a scenario for the PermoTriassic crisis. - Historical Biology 2: 289-309.

Michaelsen, P. 2002. Mass extinction of peat-forming plants and the effect on fluvial styles across the Permian-Triassic boundary, northern Bowen Basin, Australia. - Palaeogeography, Palaeoclimatology, Palaeoecology 179: 173-188.

Morante, R. 1996. Permian and Early Triassic isotopic records of carbon and strontium in Australia and a scenario of events about the Permian-Triassic boundary. - Historical Biology 11: 289-310.

Newell, A. J., Tverdokhlebov, V. P. \& Benton, M. J. 1999. Interplay of tectonics and climate on a transverse fluvial system, Upper Permian, Southern Uralian Foreland Basin, Russia. - Sedimentary Geology 127: 11-29.

Nicora, A. \& Perri, M. C. 1999. The P/T boundary in the Tesero section, western Dolomites (Trento). 3.3. Bio- and chronostratigraphy. Conodonts. In Cassinis, G., Cortesogno, L., Gaggero, L., Massari, F., Neri, C., Nicosia, U. \& Pittau, P. (eds). Stratigraphy and Facies of the Permian Deposits between Eastern Lombardy and the Western Dolomites, Field Trip Guidebook, 23-25 September 1999. International Field Conference on the 'Continental Permian of the Southern Alps and Sardinia. Regional reports and general correlations', Brescia, 15-25 September 1999. Earth Science Department, Pavia University: pp. 97-100.

Noé, S. U. 1987. Facies and Paleogeography of the marine Upper Permian and of the Permian-Triassic boundary in the Southern Alps (Bellerophon Formation, Tesero Horizon). - Facies 16: 89-142.

Oberhänsli, H., Hsü, K. J., Piasecki, S. \& Weissert, H. 1989. PermianTriassic carbon-isotope anomaly in Greenland and in the Southern Alps. - Historical Biology 2: 37-49.

Payne, J. L. \& Kump, L. R. 2007. Evidence for recurrent Early Triassic massive volcanism from quantitative interpretation of carbon isotope fluctuations. - Earth and Planetary Science Letters 256: 264-277.

Payne, J. L., Lehrmann, D. J., Wei Jia-yong, Orchard, M. J., Schrag, D. P. \& Knoll, A. H. 2004. Large perturbations of the carbon cycle during recovery from the end-Permian extinction. - Science 305: 506-509.

Peng Yuan-qiao \& Shi, G. R. 2009. Life crises on land across the Permian-Triassic boundary in South China. - Global and Planetary Change 65: 155-165.

Perri, M. C. 1991. Conodont biostratigraphy of the Werfen Formation (Lower Triassic) Southern Alps, Italy. - Bollettino della Società Paleontologica Italiana 30: 23-46.

Posenato, R. 2009. Survival patterns of macrobenthic marine assemblages during the end-Permian mass extinction in the western Tethys (Dolomites, Italy). - Palaeogeography, Palaeoclimatology, Palaeoecology 280: 150-167.

Posenato, R. 2010. Marine biotic events in the Lopingian succession and latest Permian extinction in the Southern Alps (Italy). - Geological Journal 45: 195-215

Raup, D. M. 1991. A kill curve for Phanerozoic marine species. Paleobiology 17: 37-48.

Retallack, G. J. \& Jahren, A. H. 2008. Methane release from igneous intrusion of coal during Late Permian extinction events. - Journal of Geology 116: 1-20.

Retallack, G. J., Jahren, A. H., Sheldon, N. D., Chakrabarti, R., Metzger, C. A. \& Smith, R. M. H. 2005. The Permian-Triassic boundary in Antarctica. - Antarctic Science 17: 241-258.

Riccardi, A., Kump, L. R., Arthur, M. A. \& D'Hondt, S. 2007. Carbon isotopic evidence for chemocline upward excursions during the end-Permian event. - Palaeogeography, Palaeoclimatology, Palaeoecology 248: 73-81.

Richoz, S., Krystyn, L., Baud, A., Brandner, R., Horacek, M. \& Mohtat-Aghai, P. 2010. Permian-Triassic boundary interval in the Middle East (Iran and N. Oman): Progressive environmental change from detailed carbonate carbon isotope marine curve and sedimentary evolution. - Journal of Asian Earth Sciences 39: 236-253.

Ruhl, M., Kürschner, W. M. \& Krystyn, L. 2009. Triassic-Jurassic organic carbon isotope stratigraphy of key sections in the western Tethys realm (Austria). - Earth and Planetary Science Letters 281: $169-187$.

Sageman, B. B., Meyers, S. R. \& Arthur, M. A. 2006. Orbital time scale and new $\mathrm{C}$-isotope record for Cenomanian-Turonian boundary stratotype. - Geology 34: 125-128.

Schindewolf, O. H. 1953. Über die Faunenwende vom Paläozoikum zum Mesozoikum. - Zeitschrift der Deutschen Geologischen Gesellschaft 105: 153-182.

Schönlaub, H. P. 1991. The Permian-Triassic of the Gartnerkofel-1 core (Carnic Alps, Austria): Conodont biostratigraphy. - Abhandlungen der Geologischen Bundesanstalt in Wien 45: 79-98.

Schwab, V. \& Spangenberg, J. E., 2004. Organic geochemistry across the Permian-Triassic transition at the Idrijca Valley, Western Slovenia. - Applied Geochemistry 19: 55-72.

Sephton, M. A., Veefkind, R. J., Looy, C. V., Visscher, H., Brinkhuis, H., \& de Leeuw, J. W. 2001. Lateral variations in end-Permian organic matter. In Buffetaut, E. \& Koeberl, C. (eds). Geological and biological effects of impact events. Springer, Berlin: pp. 11-24.

Sephton, M. A., Looy, C. V., Veefkind, R. J., Brinkhuis, H., de Leeuw, J. W. \& Visscher, H. 2002. Synchronous record of $\delta^{13} \mathrm{C}$ shifts in the oceans and atmosphere at the end of the Permian. In Koeberl, C. \& MacLeod, K. G. (eds). Catastrophic Events and Mass Extinctions: Impacts and Beyond. - Geological Society of America Special Paper 356: 455-462.

Sephton, M. A., Looy, C. V., Brinkhuis, H., Wignall, P. B., de Leeuw, J. W. \& Visscher, H. 2005. Catastrophic soil erosion during the end-Permian biotic crisis. - Geology 33: 941-944.

Sepkoski, J. J. 1989. Periodicity in extinction and the problem of catastrophism in the history of life. - Journal of the Geological Society 146: 7-19.

Sirevag, R., Buchanan, B. B., Berry, J. A. \& Troughton, J. H. 1977. Mechanisms of $\mathrm{CO}_{2}$ fixations in bacterial photosynthesis studied by the carbon isotope fractionation technique. - Archives of Microbiology 112: 35-38.

Summons, R. E. \& Powell, T. G. 1986. Chlorobiaceae in Palaeozoic seas revealed by biological markers, isotopes, and geology. - Nature 319: 763-765.

Svensen, H., Planke, S., Polozov, A. G., Schmidbauer, N., Corfu, F., Podladchikov, Y. Y. \& Jamtveit, B. 2009. Siberian gas venting and the end-Permian environmental crisis. - Earth and Planetary Science Letters 277: 490-500.

Thomas, B. M., Willink, R. J., Grice, K., Twitchett, R. J., Purcell, R. R., Archbold, N. W., George, A. D., Tye, S., Alexander, R., Foster, C. B. \& Barber, C. J. 2004. Unique marine Permian-Triassic boundary section from Western Australia. - Australian Journal of Earth Sciences 51: 423-430.

Tong Jin-nan, Qiu Haiou, Zhao Lai-shi \& Zuo Jing-xun. 2002. Lower Triassic inorganic carbon isotope excursion in Chaohu, Anhui Province, China. - Journal of China University of Geosciences 13 (2): 98-106.

Tong Jin-nan, Zuo Jing-xun \& Chen Zhong-qiang. 2007. Early Triassic carbon isotope excursions from South China: Proxies for devastation and restoration of marine ecosystems following the endPermian mass extinction. - Geological Journal 42: 371-389.

Twitchett, R. J., Looy, C. V., Morante, R., Visscher, H. \& Wignall, P. B. 2001. Rapid and synchronous collapse of marine and terrestrial ecosystems during the end-Permian biotic crisis. - Geology 29: 351-354.

Visscher, H., Brinkhuis, H., Dilcher, D. L., Elsik, W. C., Eshet, Y., Looy, C. V., Rampino, M. R. \& Traverse, A. 1996. The terminal Paleozoic fungal event: Evidence of terrestrial ecosystem destabilization and collapse. - Proceedings of National Academic Science of the United States of America 93: 2155-2158. 
Watson, J. S., Sephton, M. A., Looy, C. V. \& Gilmour, I. 2005. Novel oxygencontaining aromatic compounds in Permian sediment. Organic Geochemistry 36: 371-384.

Ward, P. D., Montgomery, D. R. \& Smith, R. 2000. Altered river morphology in South Africa related to the Permian-Triassic extinction. - Science 289: 1740-1743.

Whiticar, M. J. 1996. Stable isotope geochemistry of coals, humic kerogens and related natural gases. - International Journal of Coal Geology 32: 191-215.

Wignall, P. B. \& Hallam, A. 1992. Anoxia as a cause of the Permian/ Triassic mass extinction: Facies evidence from northern Italy and the western United States. - Palaeogeography, Palaeoclimatology, Palaeoecology 93: 21-46.

Yin Hong-fu, Yang Feng-qing, Yu Jian-xin, Peng Yuan-qiao, Wang Shang-yan \& Zhang Su-xin. 2007. An accurately delineated Permian-Triassic Boundary in continental successions. - Science in China Series D, Earth Sciences 50: 1281-1292.

Zhang Fan, Feng Qing-lai, He Wei-hong \& Gu Song-zhu. 2006. Stratigraphy of organic carbon isotope and associated events across the Permian/Triassic boundary in the Dongpan deep-water section in Liuqiao area, Guangxi, South China. - Geocience 20: 42-48 [in Chinese with English abstract]. 